\title{
FOSTERING A SCHOLARLY NETWORK IN INTERNATIONAL LAW: AN INTRODUCTION TO THE SPECIAL ISSUE
}

\author{
CRAIG FORCESE* AND JOANNA HARRINGTON ${ }^{* *}$ \\ SPECIAL ISSUE EDITORS
}

\begin{abstract}
This special issue of the Alberta Law Review is devoted to the discussion of current topics within the field and discipline of international law, including matters of international trade and investment law, international development, peace and security, international criminal law, and the international protection of human rights. The publication of this issue represents the culmination of an extraordinary intellectual exchange between four societies dedicated to the development and promotion of international law, which together represent five countries and attract membership from lawyers within academia, government, and private practice. The "Four Societies" initiative stems from an initial partnership in the early 1990s between the American Society of International Law (ASIL), the Canadian Council on International Law (CCIL), and the Japanese Society of International Law (JSIL), which was later expanded upon during the current decade to include the Australian \& New Zealand Society of International Law (ANZSIL). Without the support of these Four Societies, this special issue, and the two-day conference at which the articles were first presented, would not have taken place.
\end{abstract}

Together, the Four Societies have committed to fostering a scholarly network among their members, focusing in particular on their younger members as well as members who have yet to develop international networks of their own. In their first joint initiative, the Four Societies convened an international workshop in Wellington, New Zealand in 2006, organized around the general theme of "international law and democratic theory." In keeping with the initiative's focus on new and emerging scholars, the articles at this event were delivered by junior academics in the early or pre-tenure stages of their careers, or still in the midst of their doctoral programs. Revised versions of the New Zealand articles were later published as a special issue of the Victoria University of Wellington Law Review in 2007.

Following the success of the Wellington event, the Canadian Council on International Law committed to hosting the next round of this collaborative initiative in 2008, as part of the Council's 35th anniversary celebrations. The result was a workshop co-hosted by the CCIL and the Faculty of Law at the University of Alberta in September 2008, the articles from which are published in this issue of the Alberta Law Review. As in Wellington, the Edmonton colloquium was organized pursuant to the general theme of "international law and democracy" with financial support provided by the Eldon D. Foote Chair in International Law Fund, the University of Alberta Conference Fund, and the Social Sciences and Humanities Research Council of Canada, as well as the four individual societies. We remain grateful for this assistance. 


\section{DEMOCRACY AND INTERNATIONAL LAW}

International law has had traditionally little to say about democracy. All states are equal, according to the bedrock principle of sovereign equality, ${ }^{1}$ and there is no requirement, for example, in the law governing the emergence of new states that the governments of these entities be "democratic." ${ }^{2}$ As history demonstrates, illiberal and anti-democratic governments may usurp their democratic predecessors and still bind the state under international law to the point that obligations entered into by these non-democratic regimes may apply even when renounced by the more democratic governments that follow. ${ }^{3}$

On the other hand, a democratic spirit does infuse some efforts undertaken by the international community of states, especially in the area of human rights, and more specifically within the treaties drafted by states for their promotion and protection. Within the International Covenant on Civil and Political Rights, ${ }^{4}$ for instance, art. 25 recognizes and protects the right of every citizen to take part in the conduct of public affairs, the right to vote and to be elected, and the right to have access, on general terms of equality, to public service. Clearly, "[a]rticle 25 lies at the core of democratic government based on the consent of the people and in conformity with the principles of the Covenant," as recognized by the Human Rights Committee in its General Comment on art. 25, while noting that the right requires state respect of "[w]hatever form of constitution or government is in force." The Covenant also refers to a "democratic society" as the benchmark for the proper invocation by states of certain rights-limiting provisions. For example, limitations on the right of peaceful assembly and the right to freedom of association are permitted, but only those "which are necessary in a democratic society in the interests of national security or public safety, public order (ordre public), the protection of public health or morals or the protection of the rights and freedoms of others." ${ }^{6}$ The right to a fair trial is also subject to certain limitations that take into account the needs of a "democratic society."7

The question of what "democracy" means in international law is, for these reasons alone, of consequence. However, there are even more pressing reasons to examine the relationship between democracy, democratic theory, and international law. These include the progressive webbing together of a world that includes both democratic and authoritarian societies through

2 John H. Currie, Public International Law, 2d ed. (Toronto: Irwin Law, 2008) at 28; but see also Gregory H. Fox \& Brad R. Roth, eds., Democratic Governance and International Law (Cambridge: Cambridge University Press, 2000). For a classic illustration, see Arbitration between Great Britain and Costa Rica (Tinoco Case) (1923), 1 R.I.A.A. 375.

416 December 1966, 999 U.N.T.S. 171 (entered into force 23 March 1976) [ICCPR]. For commentary, see generally Sarah Joseph, Jenny Schultz \& Melissa Castan, The International Covenant on Civil and Political Rights: Cases, Materials and Commentary, 2d ed. (Oxford: Oxford University Press, 2004). General Comment No. 25: The right to participate in public affairs, voting rights and the right of equal access to public service (Art. 25), 57th Sess., UN Doc. CCPR/C/21/Rev.1/Add.7 (1996) at para. 1, reprinted in Compilation of General Comments and General Recommendations Adopted by Human Rights Treaty Bodies, UN Doc. HRI/GEN/1/Rev.9 (Vol. 1) (2008) 217. ICCPR, supra note 4, arts. 21-22.

Ibid., art. 14. 
institutions that govern and affect both. As one of us has discussed elsewhere, the internationalization of policy-making has two pointed implications for democratic states:

First, the very manner in which intergovernmental organizations function raises concerns about democratic accountability. Specifically, these institutions typically conduct their activities insulated from meaningful scrutiny by a broader public.... Second, in international policy-making, the executive branches of state governments are enhanced at the expense of the other branches. By way of example, the United Nations Security Council's powers in the United Nations Charter are expansive, and subject to broad interpretation. Its resolutions, issued pursuant to Chapter VII of the UN Charter by the Security Council's handful of members, are the most legally potent determinations of any international decision-making body. Yet, despite these broad powers, the Security Council is not subject to judicial oversight. Legislative bodies also exercise little control over international policy-making. ${ }^{8}$

The disconnect between democratic polities imbued with carefully crafted checks and balances and the blunter, less transparent, and ultimately less accountable international institutions in which these polities (and their more authoritarian counterparts) operate internationally produces tensions. As noted in the Call for Papers for the Four Societies initiative, originally penned by Professor José Alvarez of Columbia Law School during his presidency of the ASIL:

\begin{abstract}
Tensions concerning the inter-penetration of national and international law are emerging in all three branches of democratic governments. Our executive branches, attentive to the results of the most recent election that put them into power, have sometimes resisted entering into certain treaties or have attempted to make treaty reservations that would eliminate the need to change existing national law. Our national judiciaries are wrestling with whether to give effect to international law seemingly at odds with rules issued by national legislatures that give effect to the will of the electorate - a struggle that is reflected in, for example, differing assessments of whether to accord respect to the decisions of international courts or the interpretations of treaties issued by other foreign courts. Legislatures and parliaments have sometimes resisted ceding their prerogatives to international institutions (as to the WTO dispute settlement system, for example) and they have not always fully implemented treaty obligations through the issuance of national law. In some cases, they are resisting giving direct effect to international obligations, as by refusing to recognize a private cause of action to individuals for violations of customary or treaty law. And democracies that are also federations, subject to delineated powers between federal and state or provincial units within them, are also facing questions about whether or how international obligations are supposed to be accommodated given traditional notions of federalism or conceptions of residual state/provincial sovereignty. ${ }^{9}$
\end{abstract}

That same Call for Papers urged scholars from within the Four Societies to take up an examination of these sorts of issues, asking for articles dealing with "democracy and international law" in the context of such matters as: the role of national legislatures and policy-makers in the making and reception of international law, the governance of international organizations, democratic accountability in the development of trade and investment law, the application of international human rights and humanitarian law in the 
context of terrorism, and the internationalization of criminal law. The articles published in this special issue constitute the outcome of this Call for Papers, adding a Canadian chapter to the "fostering" project. The authors were selected through a national and then international process, and after presentation at the Edmonton conference, the articles were subjected to a double-blind peer review.

\section{CONTRIBUTION OF THE FOUR SOCIETIES EDMONTON WORKSHOP}

As befits the broad sweep of the "international law and democracy" focus, the articles published in this special issue reflect an eclectic mix, but one that may nevertheless be divided into several broad themes. The first two articles - those by Treasa Dunworth and Christopher Waters - address what may be loosely termed the "operationalization” of democratic values within international behaviour with a view to encouraging better governance. Dunworth's article examines the roles and responsibilities of legal advisors to international organizations, while Waters focuses on the restraints that domestic courts and quasi-judicial bodies may provide when democratic militaries act internationally. The next three articles — those by Jeremy Farrall, Paul Martin, and Kelisiana Thynne — address issues of democracy, democratic values, and international law from the perspective of several international organizations, focusing on the United Nations Security Council, the Organization of American States, and the International Criminal Court. This same focus on international organizations and democratic concepts animates the next series of articles those of Barnali Choudhury, Graham Mayeda, Yuka Fukunaga, and Andrew Mitchell, the latter co-writing with Elizabeth Sheargold. Each of these articles focuses on international trade and investment and the institutional context in which these business activities occur, highlighting the democratic implications of such bodies as the World Trade Organization and the legal regime associated with bilateral investment treaties. The final four articles are more theoretical in perspective, some looking backwards to history to understand the present, and others facing forward and examining what may be termed "frontier issues" within international law. Tetsuya Toyoda and Yoshiaki Sato examine the past to understand the evolution of international law during a period of emerging democratization, and in Sato's case, glean lessons from the philosophical traditions of the period. Kathryrn Bryk Friedman, for her part, focuses on contemporary North America, examining the deepening integration between Canada and the United States, and the implications of resulting transgovernmental networks for international law and the continent's governance. Finally, Molly Beutz Land looks to the levelling and democratizing implications of new technologies and the information revolution in examining the future of human rights investigations and reporting.

\section{LOOKING TO THE FUTURE}

The Four Societies initiative will not end with this special issue. At the Edmonton workshop in September 2008, the JSIL generously offered to host the next colloquium, to be held in Awaji, Japan in August 2010. Planning for that event is underway, and it is anticipated that, once again, each of the Four Societies will be selecting new voices and emerging scholars to present articles on a specified theme, currently under discussion. In the interim, we hope that the articles published in this special issue will foster their own discussions among international lawyers, whether in academia, government, or private 
practice, while also widening the discussion of the relationship between democracy and international law.

We conclude this introduction with several words of heartfelt appreciation. Thanks are due to our colleagues on the Four Societies steering committee: Elizabeth Andersen, José Alvarez, Campbell McLachlan, Yoshiaki Sakurada, and Norio Tanaka. The support of the then-presidents of each of the Four Societies over the course of this project has been invaluable, as has the support of the Presidents not already named above: Valerie Hughes, Yuji Iwasawa, and Lucy Reed. Thanks are also due to Professor Donald McRae, holder of the Hyman Soloway Chair in Business and Trade Law at the University of Ottawa and a member of the International Law Commission, who delivered a stimulating keynote address at the Edmonton workshop, and to Professors Diane Marie Amann, Don Anton, and Shigeki Sakamoto who ably served as expert commentators. We also thank the anonymous peer reviewers from the academy and government who reviewed and commented on each article in draft, and we are extremely grateful to the team at the Alberta Law Review, led by CoEditors-in-Chief Ellen Hong and Lora Lee (2008-2009) and Dana Adams and Nancy Jacobsen (2009-2010), whose diligence made this publication possible. Lastly, one of us more than the other owes the thanks of all who participated for bringing this project to a successful conclusion: Craig Forcese would like to extend special recognition to Joanna Harrington for her tireless efforts in organizing the Edmonton conference and the subsequent publication of this special issue.

The Alberta Law Review gratefully acknowledges the financial support of the Social Sciences and Humanities Research Council of Canada towards the publication of this special issue. 
This page is blank - do not strip it in 